\title{
Peran Model Pembelajaran Kooperatif Tipe CRH Berbantuan Media Visual Terhadap Hasil Belajar IPA Siswa SD
}

\author{
Ni Ketut Ayu Tri Yanayanti \\ Jurusan Pendidikan Dasar, Universitas Pendidikan Ganesha \\ triyanayantiayu@gmail.com
}

\author{
DB. Kt. Ngr. Semara Putra \\ Jurusan Pendidikan Dasar, Universitas Pendidikan Ganesha \\ Semara.putra@undiksha.ac.id (9Pt)
}

I. G. A Agung Sri Asri

Jurusan Pendidikan Dasar, Universitas Pendidikan Ganesha igaagungsri.asri@undiksha.ac.id

\begin{tabular}{l} 
A R T I C L E I N F O \\
\hline Article history: \\
1 Juli 2020 Received in \\
revised form \\
30 Agustus 2020 \\
Accepted 28 September 2020 \\
Available online \\
30 September 2020 \\
Kata Kunci: \\
CRH, media visua, hasil \\
belajar \\
Keywords: \\
CRH, visual media, \\
achievement learning
\end{tabular}

\begin{abstract}
AB S T R A K
$\overline{\text { Penelitian ini bertujuan untuk mengetahui pengaruh yang }}$ signifikan model pembelajaran kooperatif tipe Course Review Horay berbantuan media visual. Jenis penelitian ini merupakan eksperimen semu dengan desain penelitian nonequivalent control group design. Sampel ditentukan dengan teknik random sampling. Penelitian ini menggunakan kelompok eksperimen yang berjumlah 32 siswa dan kelompok kontrol berjumlah 37 siswa. Pengumpulan data hasil belajar IPA dilakukan dengan metode tes dengan instrumen tes objektif. Hasil analisis data menggunakan uji-t memperoleh thitung $=6,611$ pada taraf signifikansi $5 \%$ dan $\mathrm{dk}=67$ dengan nilai ttabel $=$ 1,993 sehingga $\mathrm{t}$ hitung $=6,611>\mathrm{t}$ tabel $=1,993$. Berdasarkan kriteria pengujian maka $\mathrm{H} 0$ ditolak dan $\mathrm{Ha}$ diterima. Ini berarti terdapat perbedaan yang signifikan
\end{abstract} hasil belajar IPA antara kelompok yang dibelajarkan dengan menggunakan model pembelajaran Corse review Horay dan kelompok yang dibelajarkan dengan menggunakan pembelajaran konvensional. Rata-rata hasil belajar IPA siswa kelompok eksperimen dan kelompok kontrol yaitu 87,031 > 1993. Dengan demikian dapat disimpulkan, model pembelajaran kooperatif tipe Course Review Horay berbantuan media visual berpengaruh terhadap hasil belajar IPA SD.

\begin{abstract}
This study aims to determine the significant effect of the Course Review Horay type of cooperative learning model assisted by visual media. This type of research is a quasi experiment with nonequivalent control group design. The sample is determined by random sampling technique. This study used an experimental group totaling 32 students and a control group totaling 37 students. The data collection of science learning outcomes was carried out by test method with multiple choice test instruments. The results of data analysis using t-test obtained $t$-count $=6.611$ at a significance level of $5 \%$ and $d k=67$ with a value of $t$-table $=$ 1.993 so that $t$ count $=6.611>t$ table $=1.993$. Based on the criteria, $\mathrm{HO}$ is rejected and $\mathrm{Ha}$ is accepted. This means that there is a significant difference in science learning outcomes between the groups taught using the Corse review Horay learning model and the groups taught using conventional learning. The average science learning outcomes of students in the experimental group and the control group were 87.031>1993. Thus, it can be concluded that the Course Review Horay type of cooperative learning model assisted by visual media has an effect on the students science learning outcomes in elementary school.
\end{abstract}




\section{PENDAHULUAN}

Pendidikan sebagai salah satu usaha manusia mengembangkan potensi dirinya untuk memiliki kekuatan spiritual keagamaan, pengendalian diri, kepribadian, kecerdasan, akhlak mulia, serta keterampilan yang diperlukan. Mahardita menjelaskan pendidikan adalah segala pengaruh yang diupayakan sekolah terhadap anak dan remaja yang diserahkan kepadanya agar mempunyai kemampuan yang sempurna dan kesadaran penuh terhadap hubungan-hubungan dan tugas-tugas sosial mereka (Mahardita, G. A. M. C., \& Abadi, 2017). Pendidikan menjadi pilar utama dalam mewujudkan perubahan manusia kearah yang positif dan menuju pencapaian potensi kemanusiaan tertinggi. Hal tersebut berarti bahwa pendidikan harus menjadi skala prioritas yang utama manusia agar manusia mempunyai arah dan tujuan yang jelas mengenai apa yang dikerjakan dan dipilih untuk memenuhi kebutuhan hidupnya. Aryastuti menyebutkan pendidikan bertujuan untuk mengembangkan segala potensi yang ada pada peserta didik agar nantinya dapat menciptakan generasi yang berkualitas yang berguna bagi masyarakat, bangsa dan Negara (Aryastuti, N. M., Suarni, N. K., \& Kusmariyatni, 2017). Untuk meningkatkan kualitas sumber daya manusia dan mencapai tujuan pendidikan nasional, pemerintah telah menyelenggarakan berbagai upaya. Dalam pendidikan mencakup dua konsep yang berhubungan yaitu belajar dan pembelajaran. Konsep belajar mencakup peserta didik sedangkan konsep pembelajaran berakar pada pihak pendidik. Tindakan atau usaha yang dirancang oleh pendidik untuk mendukung proses belajar peserta didik melalui kegiatankegiatan diartikan sebagai suatu proses pembelajaran. Dalam proses pembelajaran terjadi proses interaksi antara peserta didik dengan pendidik.

Dalam dunia pendidikan terdapat kurikulum yang mempunyai kedudukan sentral dalam seluruh proses pendidikan. Kurikulum pendidikan di Indonesia selalu ada inovasi sesuai dengan globalisasi dan mempunyai tantangan untuk kemajuan Sumber Daya Manusia (SDM). Kurikulum yang pernah dipakai yaitu mulai dari Kurikulum Berbasis Kompetensi (KBK), Kurikulum Tingkat Satuan Pendidikan (KTSP) dan yang terbaru Kurikulum 2013 (Aryastuti, N. M., Suarni, N. K., \& Kusmariyatni, 2017). Salah satu tantangan nyata tersebut adalah pendidikan hendaknya mampu bersaing secara global. Oleh karena itu pengelolaan pendidikan harus berorientasi pada bagaimana menciptakan perubahan dan pengembangan mutu pendidikan di Indonesia, serta sebagai upaya telah dilaksanakan hampir di semua komponen pendidikan. Proses pembelajaran pada kurikulum 2013 untuk semua jenjang dilaksanakan dengan menggunakan pendekatan ilmiah (saintifik). Pembelajaran dalam kurikulum 2013 menggunakan sistem tema (tematik integratif) Dimana dalam beberapa pertemuan siswa mempelajari beberapa muatan materi yang tergabung dalam satu tema (Wiranata, I. M., \& Japa, 2018). Tema merajut makna berbagai konsep dasar sehingga siswa tidak belajar secara parsial. Siswa dituntut melalui beberapa proses secara aktif mencari, mengolah, mengontruksi, dan menerapkan pengetahuan berdasarkan langkah-langkah pendekatan saintifik dalam kurikulum 2013. Maka sangat siperlukan upaya inovasi dari guru dalam mengreasikian pembelajaran di kelas agar kelihatan lebih menarik dan tidak membosankan. Dalam merancang suatu pembelajaran, harus memperhatikan tujuan diselenggarakannya pembelajaran itu sendiri, termasuk didalam pembelajaran Ilmu Pengetahuan Alam (IPA).

IPA merupakan salah satu cabang ilmu pengetahuan yang memegang peranan penting dalam perkembangan IPTEKS. Sari menyatakan bahwa IPA (Ilmu Pengetahuan Alam) secara garis besar berarti suatu cabang ilmu sains yang mempelajari fenomena alam 
melalui observasi dan menganalisis bukti-bukti empiris sehingga mampu menjabarkan, memprediksi dan memahami fenomena alam tersebut (Sari, I. G. A. K. D. P., Mahadewi, L. P. P, \& Rati, 2017). IPA merupakan ilmu yang pada awalnya diperoleh dan dikembangakan berdasarkan percobaan (induktif) namun pada perkembangan selanjutnya IPA juga diperoleh dan dikembangkan berdasarkan teori (deduktif). Ada dua hal berkaitan yang tidak terpisahkan dengan IPA, yaitu IPA sebagai produk, Pengetahuan IPA yang berupa pengetahuan faktual, konseptual, procedural, dan metakognitif, dan IPA sebagai proses yaitu kerja ilmiah (Sulistyowati., 2015). Widura, I. D. G. S., Tegeh, I. M., \& Suwatra (2018) menyatakan bahwa pembelajaran IPA diarahkan untuk mengutamakan penelitian dan pemecahan masalah. Pembelajaran IPA dapat diklasifikasikan menjadi tiga bagian, yaitu IPA sebagai produk, proses, dan sikap ilmiah. IPA sebagai produk, adalah hasil-hasil penelitian yang telah ilmuan lakukan dan sudah membentuk konsep yang telah dikaji sebagai kegiatan empiris dan analitis. Sebagai proses, adalah untuk menggali dan memahami pengetahuan tentang alam. Sebagai sikap, adalah sikap ilmiah yang dikembangkan dalam pembelajaran melalui kegiatan ilmiah. Pembelajaran IPA seharusnya diupayakan mengarah pada pencapaian tujuan IPA sehingga terbentuk pengalaman belajar yang lebih bermakna. Sejalan dengan pendapatnya, Septiawan, I. M. A. E., Rati, N. W., \& Murda (2017) menyatakan bahwa Untuk dapat mewujudkan harapan pendidikan IPA, proses pembelajarannya harus menekankan pada pemberian pengalaman langsung kepada siswa untuk mengembangkan kompetensi dan memahami alam sekitar secara ilmiah. IPA merupakan mata pelajaran yang sangat penting bagi kehidupan siswa. Pembelajaran demikian perlu dilakukan pada semua jenjang pendidikan, termasuk di SD. Tujuan pembelajaran IPA di SD adalah pemahaman terhadap disiplin keilmuan IPA dan keterampilan berkarya (proyek) untuk menghasilkan suatu produk sebagai hasil belajarnya. Tujuan tersebut dapat tercapai jika pembelajaran IPA diorientasikan pada aktivitasaktivitas yang mendukung terjadinya pemahaman terhadap konsep, prinsip, dan prosedur dalam kaitannya dengan konteks kehidupan mereka seharihari. Maka dari itu pembelajaran IPA merupakan pembelajaran mengenai ilmu pengetahuan yang berkaitan dengan alam semesta melalui pengamatan dan prosedur yang tepat dalam mendapatkan suatu kesimpulan.

Dengan demikian pembelajaran IPA menjadi bermakna dan menyenangkan. Namun kenyataannya di lapangan, pembelajaran IPA masih jauh dari harapan. Menurut Diarsa, I. P., Murda, I. N., \& Dharmayanti (2017) Pembelajaran IPA di sekolah dasar, diajarkan kepada siswa tidak hanya sebatas materi dan hapalan saja, karena pembelajaran yang seperti itu tidak semua siswa dapat mengikutinya. Berdasarkan hasil observasi pada kelas IV di 6 SD yang ada di gugus II Teuku Umar pada, pembelajaran IPA belum mencerminkan kegiatan yang bermakna dan menyenangkan. Hal ini disebabkan karena guru selalu menggunakan model pembelajaran konvensional. Pembelajaran konvensional yang dimaksud adalah pembelajaran yang menggunakan metode yang biasa dilakukan oleh guru, yaitu memberi materi melalui ceramah, latihan soal, kemudian pemberian tugas. Akibatnya, guru terkesan lebih aktif dalam pembelajaran daripada siswa. Pembelajaran yang demikian membuat siswa tidak menyukai IPA, sejalan dengan pendapat dari Sari, M. I., Riastini, P. N., \& Suarjana (2017) yang menyatakan, proses pembelajaran konvensional sepenuhnya ada pada kendali guru, dimana dalam pembelajaran konvensional pembelajaran masih berpusat pada guru. Dalam hal ini penggunaan pembelajaran konvensional siswa tidak menjadi aktif dalam kegiatan belajar mengajar.Sumber belajar 
dalam pembelajaran konvensional lebih banyak menggunakan informasi yang dilakukan secara verbal maupun ceramah.

Berdasarkan observasi yang telah dilakukan dari 185 siswa kelas IV dalam gugus II Teuku Umar terdapat 70,72\% atau sekitar 130 siswa belum mencapai KKM dan 29,72\% atau sekitar 55 siswa yang sudah mencapai KKM, jadi jumlah siswa yang tidak lulus KKM lebih banyak dari pada siswa yang sudah lulus KKM dalam mata pelajaran IPA. Untuk mengatasi masalah tersebut dilakukan penelitian sebagai solusi untuk memecahkan permasalahan. Untuk itu perlu diadakan situasi pembelajaran yang menyenangkan dan merangsang minat siswa untuk lebih antusias berperan aktif dalam proses pembelajaran. Pada penelitian ini model pembelajaran kooperatif tipe Course Review Horay diharapkan tepat dalam melaksanakan pembelajaran siswa agar hasil belajar dapat tercapai optimal pada mata pelajaran IPA. Dengan menggunakan model pembelajaran kooperatif tipe Course Review Horay yang merupakan model pembelajaran yang dapat menciptakan susasana kelas menjadi meriah dan menyenangkan karena setiap siswa yang dpat menjawab benar maka siswa tersebut diwajibkan berteriak "hore" atau yel-yel lain yang disepakati. (Kurniasih, n.d.). Rahmawati, F. F., \& Prasetya (2019) menyatakan bahwa model pembelajaran Course Review Horay mendorong siswa untuk aktif dalam belajar, membangun dan membentuk pengetahuannya sendiri dengan bimbingan guru. Model Course Review Horay lahir dari epistemologi konstruktivisme karena model pembelajaran ini memberikan kesempatan yang luas bagi siswa untuk aktif dalam belajar sehingga fokus pembelajaran beralih dari berfokus pada guru menjadi berfokus pada siswa. Yanthi (2017) berpendapat bahwa Melalui model Course Review Horay, siswa diharapkan dapat berlatih untuk menyelesaikan pertanyaan bersama kelompok. Model Course Review Horay juga merupakan suatu model pembelajaran dengan pengujian pemahaman siswa. Selain hal tersebut model ini sangat menyenangkan dikarenakan diselingi dengan hiburan yang akan mampu meningkatkan semangat siswa dalam pembelajaran.

Dalam penelitian ini model pembelajaran Corse Riview Horay berbantuan media visual. Media visual merupakan sebuah sebuah media yang memiliki beberapa unsur berupa garis, bentuk, warna, dan tekstur dalam penyajiannya. Media visual dapat menampilkan keterkaitan isi materi yang ingin disampaikan dengan kenyataan. Media visual adalah media yang melibatkan indera penglihatan. Media visual sebagai sumber belajar yang berisikan pesan atau materi pelajaran yang dibuat secara menarik dalam bentuk kombinasi gambar, teks, gerak dan animasi yang disesuaikan dengan kebutuhan dan usia peserta didik (Agustin, N. K. T. J., Margunayasa, I. G., \& Kusmariyatni, 2019). Media visual digunakan agar dapat menarik peserta didik dalam belajar, sehingga pembelajaran akan menyenangkan dan tidak menjenuhkan (Ega Rima Wati, 2016). Keberhasilkan penggunaan media berbasis visual ditentukan oleh kwalitas dan evektivitas bahan-bahan visual dan grafis itu. Hal ini hanya dapat dicapai dengan mengatur dan mengorganisasikan gagasan-gagasan yang timbul, merencanakannya dengan seksama,dan menggunakan teknis-teknis dasar visualisasi objek, konsep, infoemasi, atau situasi (Arsyad, 2017).

Berdasarkan uraian tersebut, secara teoritis model pembelajaran kooperatif tipe Corse Review Horay berpengaruh terhadap hasil belajar siswa, tetapi secara empiris perlu dibuktikan melalui penelitian. tujuan penelitian ini untuk mengetahui pengaruh model pembelajaran Course Review Horay berbantuan media visual terhadap hasil belajar IPA siswa kelas IV SD Gugus II Teuku Umar Tahun Ajaran 2019/2020. 


\section{METODE PENELITIAN}

Penelitian ini dilaksanakan di SD Gugus II Teuku Umar Denpasar Barat yang terdiri dari 6 SD antara lain SD Negeri 2 Dauh Puri, SD Negeri 21 Dauh Puri, SD Negeri 12 Dauh Puri, SD Negeri 10 Dauh Puri, SD Negeri 13 dauh Puri, dan SD Negeri 14 Dauh Puri. Dalam pelaksanaan penelitian ini dilakukan pada kelas kontrol dan kelas eksperimen yang sudah diuji kesetaraannya.

Waktu pelaksanaan penelitian dilaksanakan selama 1 bulan di dua SD yang ada di Gugus II Teuku Umar Denpasar Barat. Yang merupakan sampel dalam penelitian ini yaitu SD Negeri 14 Dauh Puri yang sebagai kelompok eksperimen dan SD Negeri 10 Dauh Puri yang sebagai kelompok kontrol. Pelaksanaan penelitian pada kelompok eksperimen dan kelompok kontrol terdiri atas pemberian pretest kepada kelompok control dan kelompok eksperimen, memberikan perlakuan selama 6x kepada kelompok eksperimen dan memberikan posttest kepada kelompok control dan kelompok eksperimen.

Penelitian ini dilakukan pada siswa kelas IV SD DI Gugus II teuku Umar Denpasar Barat tahun pelajaran 2019-2020. Penelitian ini adalah penelitian eksperimen dengan menggunakan desain eksperimen semu (Quasy Exsperiment). Menurut (Sugiyono, 2017)"Desain ini memiliki kelompok kontrol, tetapi tidak bisa sepenuhnya mengontrol variabel-variabel luar yang mempengaruhi pelaksanaan eksperimen". Hal ini dikarenakan kemampuan peneliti dalam mengamati perilaku siswa sangat terbatas terutama ketika siswa berada di luar sekolah (rumah), peneliti juga tidak memiliki kemampuan untuk mengetahui persepsi siswa terhadap perlakuan secara pasti.

Rancangan eksperimen semu yang akan digunakan dalam penelitian ini adalah "Nonequilevalent Control Group Design". Dalam rancangan ini terdapat pretest dan posttest. Sebelum diberikan perlakuan kelompok eksperimen dan kelompok kontrol akan deberikan pretest terlebih dahulu untuk mengukur ekuivalensi atau dapat disebut penyetaraan kelompok. Berdasarkan hal tersebut, maka dalam penelitian ini pretes digunakan untuk mengetahiu keadaan awal pengetahuan siswa. Setelah meberikan pretest langkah selanjutnya peneliti akan memberikan perlakuan kepada kelompok eksperimen yaitu pembelajaran yang menggunakan model pembelajaran kooperatif tipe Course Riview Horay berbantuan media visual.

Kelompok kontrol tidak diberikan perlakuan yang sama tetapi pembelajaran dilakukan seperti biasa dengan menggunakan model pembelajaran konvensional yang dilaksanakan oleh guru dikelas. Setelah diberikan perlakuan dilakukan posttest untuk mengetahui penguasaan kompetensi pengetahuan siswa yang dibelajarkan menggunakan metode pembelajaran kooperatif tipe Course Review Horay berbantuan media visual dengan siswa yang dibelajarkan dengan metode pembelajaran konvensional. Berdasarkan hal tersebut pretest digunakan untuk penyetaraan kelompok dan posttest digunakan untuk mengetahui seberapa penguasaan kompetensi pengetahuan yang dimiliki oleh siswa. Penelitian ini bertujuan untuk mengetahui pengaruh penerapan model pembelajaran model Course Riview Horay benbantuan media visual terhadap hasil belajar IPA siswa.

Populasi dalam penelitian ini adalah siswa kelas IV di SD Negeri yang terdapat pada Gugus II Teuku Umar Tahun Ajaran 2019/2020. Populasi dapat dikatakan "wilayah generalisasi yang terdiri atas: obyek/subyek yang mempunyai kualitas dan karakteristik tertentu yang ditetapkan oleh peneliti untuk dipelajari dan kemudian ditarik kesimpulannya" (Sugiyono, 2017). Selanjutnya, Agung (2014) menyatakan bahwa "populasi adalah keseluruhan objek dalam suatu penelitian". Jadi, populasi pada prinsipnya 
adalah semua anggota kelompok yang tinggal bersama dalam satu tempat dan menjadi target kesimpulan dari hasil akhir suatu penelitian. Populasi penelitian ini adalah siswa kelas IV SD Gugus II Teuku Umar Denpasar Barat tahun ajaran 2019/2020 yang terdiri dari 6 sekolah yang terdiri dari SD Negeri 2 Dauh Puri, SD Negeri 21 Dauh Puri, SD Negeri 12 Dauh Puri, SD Negeri 10 Dauh puri, SD Negeri 13 Dauh Puri, dan SD Negeri 14 Dauh Puri.

Pengambilan sampel pada penelitian ini dilakukan dengan teknik random sampling. “Teknik random sampling adalah teknik penentuan sampel secara acak" (Sugiyono, 2017). Teknik random yang digunakan dalam penelitian ini yaitu dengan cara undian yang dirandom adalah SD, sehingga setiap SD mendapat peluang yang sama untuk menjadi sampel penelitian. Pemilihan sampel penelitian ini tidak dilakukannya pengacakan individu, karena tidak bisa mengubah kelas yang telah terbentuk sebelumnya. Kelas yang dipilih telah terbentuk tanpa campur tangan peneliti dan tidak dilakukannya pengacakan individu, kemungkinan pengaruh-pengaruh dari keadaan subjek mengetahui dirinya dilibatkan dalam penelitian dapat dikurangi sehingga penelitian ini benar-benar menggambarkan pengaruh perlakuan yang diberikan.

Penentuan sampel yang dipilih menjadi kelompok control dan kelompok eksperimen dilakukan dengan cara pengundian. Pengundian dilakukan agar semua anggota populasi memiliki kesempatan yang sama untuk dipilih menjadi sampel penelitian. Kelas yang dijadikan kelas eksperimen dan kelas control saat pengambilan sampel harus memenuhi syarat representative, artinya sampel yang diambil benar-benar mewakili populasi yang ada. Teknik undian ini menggunakan potongan kertas yang dituliskan masing-masing nama anggota populasi kemudian digulung dan dimasukan kedalam botol. Kertas gulungan dalam botol tersebut kemudian dikocok sehingga diperoleh dua gulungan kertas. Nama yang tercantum pada gulungan kertas tersebut merupakan sampel penelitian. Kedua yang keluar dalam undian kemudian di beri pre test dengan tujuan untuk menyetarakan kedua kelompok.

Hasil nilai atau skor pre test yang diperoleh dianalisis menggunakan uji-t untuk diperoleh kelas yang setara. Seebelum uji kesetaraan menggunakan uji-t, kedua kelompok diuji prasyarat yaitu normalitas sebaran data dan uji homogenitas varians dengan menggunakan Kolmogorof-Smirnov. Pengambilan sampel pada penelitian ini dilakukan dengan teknik random sampling. "Teknik random sampling adalah teknik penentuan sampel secara acak" (Sugiyono, 2017). Teknik random yang digunakan dalam penelitian ini yaitu dengan cara undian yang dirandom adalah SD, sehingga setiap SD mendapat peluang yang sama untuk menjadi sampel penelitian. Pemilihan sampel penelitian ini tidak dilakukannya pengacakan individu, karena tidak bisa mengubah kelas yang telah terbentuk sebelumnya. Kelas yang dipilih telah terbentuk tanpa campur tangan peneliti dan tidak dilakukannya pengacakan individu, kemungkinan pengaruh-pengaruh dari keadaan subjek mengetahui dirinya dilibatkan dalam penelitian dapat dikurangi sehingga penelitian ini benar-benar menggambarkan pengaruh perlakuan yang diberikan.

Penentuan sampel yang dipilih menjadi kelompok kontrol dan kelompok eksperimen dilakukan dengan cara pengundian. Pengundian dilakukan agar semua anggota populasi memiliki kesempatan yang sama untuk dipilih menjadi sampel penelitian. Kelas yang dijadikan kelas eksperimen dan kelas kontrol saat pengambilan sampel harus memenuhi syarat representative, artinya sampel yang diambil benar-benar mewakili populasi yang ada. Teknik undian ini menggunakan potongan kertas yang dituliskan masing-masing nama 
anggota populasi kemudian digulung dan dimasukan kedalam botol. Kertas gulungan dalam botol tersebut kemudian dikocok sehingga diperoleh dua gulungan kertas. Nama yang tercantum pada gulungan kertas tersebut merupakan sampel penelitian. Kedua yang keluar dalam undian kemudian di beri pre test dengan tujuan untuk menyetarakan kedua kelompok.

Hasil nilai atau skor pre test yang diperoleh dianalisis menggunakan uji-t untuk diperoleh kelas yang setara. Seebelum uji kesetaraan menggunakan uji-t, kedua kelompok diuji prasyarat yaitu normalitas sebaran data dan uji homogenitas varians dengan menggunakan. Berdasarkan hasil analisis uji-t pada taraf signifikansi 5\% dan derajat kebebasan $\mathrm{dk}=(\mathrm{n} 1+\mathrm{n} 2-2)=67$ didapat thitung $=1,989$ dan ttabel $=2,000$ Sehingga thitung $=1,989<$ Ttabel 2,000. Berdasarkan uji-t kesetaraan yang dilakukan dapat disimpulkan bahwa kedua kelas tersebut setara.

Setelah diketahui kedua kelompok setara maka dilakukan pengundian kembali untuk menentukan kelas ekspetimen dan kelasn kontrol. Berdasarkan hasil pengundian diperoleh kelas eksperimen yang diberi perlakuan model pembelajaran kooperatif tipe Course Review Horay berbantuan media visual dan kelas kontrol yang melaksanakan pembelajaraan dengan menggunakan pendekatan saintifik.

Dalam penelitian ini data yang akan dikumpul dan dianalisi adalah data hasil belajar IPA siswa kelas IV SD Negeri Gugus II Teuku Umar Denpasar Barat tahun ajaran 2019/2020. Data hasil belajar IPA dikumpulkan dengan tes hasil belajar IPA. Terdapat dua metode yang dipilih untuk mengumpulkan data yaitu metode tes dan metode non tes. Metode yang digunakan pada penelitian ini adalah metode tes, mengingat data yang ingin dikumpulkan bersifat kuantitatif. Dalam penelitian ini data yang diperlukan adalah data tentang hasil belajar IPA SD siswa. Untuk mengumpulkan data tersebut digunakan tes, yaitu tes hasil belajar IPA dan disusun sendiri oleh peneliti. Bentuk tes yang digunakan dalam penelitian ini adalah tes objektif tipe pilihan ganda biasa. Dalam tes objektif ada dua kemungkinan jawaban, yaitu betul dan salah. Setiap soal disertai empat alternatif jawaban yang dipilih siswa (alternatif a,b,c dan d). Setiap item diberikan skor 1 bila siswa menjawab dengan benar (jawaban disesuaikan dengan kunci jawaban) serta skor 0 untuk siswa yang menjawab salah. Skor setiap jawaban kemudian dijumlahkan dan jumlah tersebut merupakan skor variabel hasil belajar siswa. Hasil validitas diberikan kepada siswa kelompok eksperimen dan kelompok kontrol untuk mengetahui kemampuan hasil belajar IPA. Tes yang baik harus memenuhi syarat ketepatan (validitas) dan keajegan atau ketepatan (reliabilitas) Untuk itu, sebelum tes tersebut digunakan terlebih dahulu tes diuji validitas, reliabilitas, daya beda dan indeks kesukarannya.

Hasil belajar IPA merupakan refleksi kebiasaan berpikir yang memuat pengetahuan, ketrampilan dan nilai dasar mata pelajaran IPA yang kemudian diukur dan diamati. Pada penelitian ini berpedoman pada kisi-kisi soal. Penyusunan kisi-kisi mengacu pada kompetensi inti pengetahuan, kompetensi dasar, dan indicator. Indicator yang akan disusun pada penelitian ini adalah indicator yang digunakan untuk mengukur hasil belajar IPA siswa kelas IV yang diukur pada penelitian ini terbatas pada jenjang kemampuan berpikir yaitu mengingat $(\mathrm{C} 1)$, memahami $(\mathrm{C} 2)$, menerapkan $(\mathrm{C} 3)$, menganalisis $(\mathrm{C} 4)$.

Berdasarkan tujuan dari penelitian ini yaitu Untuk mengetahui pengaruh model pembelajaran Course Review Horay berbantuan media visual terhadap hasil belajar IPA maka metode yang digunakan dalam penelitian ini adalah statistik Inferensial. Statistik Inferensial adalah teknik statistik yang digunakan untuk menganalisis data sampel dan 
hasilnya diberlakukan untuk populasi (Sugiyono, 2017). Ada dua uji prasyarat yang harus dipenuhi, sebelum dilakukan analisis data utama untuk menguji hipotesis penelitian yaitu uji normalitas sebaran data tiap kelompok dan uji homogenitas varians antar kelompok.

Uji normalitas bertujuan untuk mengetahui apakah data berdistribusi normal atau tidak. Pengujian normalitas data pada penelitian ini digunakan untuk mengetahui apakah sebaran data skor variabel bebas yaitu model pembelajaran kooperatif tipe Course Review Horay berbantuan media visual serta variabel terikat hasil belajar IPA siswa kelas IV SD Negeri Gugus II Teuku Umar normal atau tidak sehingga dapat menentukan teknik analisis data. Uji normalitas dalam penelitian ini menggunakan teknik Kolmogorov-Smirnov. Bila probabilitas data lebih besar daripada 0,05 berarti data berdistribusi normal. Sedangkan bila probabilitas data lebih kecil dari 0,05 berarti data tidak berdistribusi normal. Bila data berdistribusi normal maka dapat digunakan uji statistic parametrik, sedangkan bila data tidak berdistribusi normal maka dapat digunakan uji statistik non-parametrik.

Uji homogenitas dilakukan untuk menunjukan bahwa perbedaan yang terjadi pada uji hipotes benar-benar terjadi akibat adanya perbedaan varians antara kelompok, bukan sebagai akibat perbedaan dalam kelompok. Uji homogenitas varians dilakukan dengan uji Fisher (F). Kriteria dalam pengujian ini adalah jika Fhitung < Ftabel, maka kedua kelompok data homogen. Sebaliknya jika Fhitung > Ftabel, maka kelompok data tidak homogen. Pengujian dilakukan pada taraf signifikan 5\% dengan derajat kebebasan untuk pembilang $\mathrm{n} 1$ - 1 dan derajat kebebasan untuk penyebut $\mathrm{n} 2-1$. Data yang telah diuji normalitas dan homogenitasnya maka akan diuji hipotesisnya.

Analisis statistik yang digunakan untuk menguji hipotesis penelitian ini adalah uji beda mean (uji-t). uji hipotesis menggunakan uji-t dengan rumus polled varians. Rumus uji $-t$ dengan rumus polled varians digunakan karena jumlah anggita sampel sama $(n 1=n 2)$ dan varians homogen. Krteria pengujian adalah harga th itung < , maka H0 diterima dan Ha ditolak, dan jika thitung > ttabel maka H0 ditolak dan Ha diterima dan kelompok dinyatakan tidak setara. Pada taraf signifikansi 5\% dengan $d k=n 1+n 2-2$.

\section{HASIL DAN PEMBAHASAN}

\section{HASIL}

Berdasarkan penjabaran nilai hasil belajar IPA kelas eksperimen diketahui bahwa, siswa yang mendapatkan nilai lebih dari sama dengan KKM 70 dengan nilai 70 diperoleh 1 siswa atau 3,1\% dari 32 siswa. Nilai 73 diperoleh 2 siswa atau 6,2\% dari 32 siswa. Nilai 78 diperoleh 3 siswa atau 9,3\% dari 32 siswa. Nilai 80 diperoleh 2 siswa atau 6,2\% dari 32 siswa. Siswa yang mendapatkan nilai 83 diperoleh 1 siswa atau 3,1\% dari 32 siswa. Siswa yang mendapatkan nilai 85 diperoleh 4 siswa atau 12\% dari 32 siswa. Siswa yang mendapatkan nilai 88 diperoleh 2 siswa atau 6,2\% dari 32 siswa. Siswa yang mendapatkan nilai 90 diperoleh 4 siswa atau 12\% dari 32 siswa. Siswa mendapatkan nilai 93 diperoleh 4 siswa atau $12 \%$ dari 32 siswa. Siswa yang mendapatkan nilai 95 diperoleh 5 siswa atau 15,6\% dari 32 siswa. Dan yang terakhir siswa yang mendapatkan nilai 98 diperoleh 3 siswa atau $9,3 \%$ dari 32 siswa.

Dari pemaparan data hasil belajar IPA siswa kelas IV kelompok kontrol pada tabel 4.4 yaitu siswa yang mendapatkan nilai lebih dari sama dengan KKM 65 dengan nilai 65 diperoleh 4 siswa atau 10,8\% dari 37 siswa. Nilai 68 diperoleh 4 siswa atau 10,8\% dari 37 siswa. Nilai 70 diperoleh 6 siswa atau 16,2\% dari 37 siswa. Nilai 73 diperoleh 4 siswa atau $10,8 \%$ dari 37 siswa. Siswa yang mendapatkan nilai 78 diperoleh 9 siswa atau $24,3 \%$ dari 
37 siswa. Siswa yang mendapatkan nilai 80 diperoleh 3 siswa atau 8,1\% dari 37 siswa. Siswa yang mendapatkan nilai 83 diperoleh 1 siswa atau 2,7\% dari 37 siswa. Siswa yang mendapatkan 85 diperoleh 2 siswa atau 5,4\% dari 37 siswa. Dan yang terakhir siswa yang mendapatkan nilai 88 diperoleh 4 siswa atau $10,8 \%$ dari 37 siswa.

Untuk mengetahui sebaran data tersebut, dilakukan uji normalitas sebaran data dengan tekik Kolmogorov-Smirnov. Kriteria pengujian pada uji normalitas adalah signifikansi uji paada $D_{\text {hitung }}$ dibandingkan nilai $D_{\text {tabel }}$ Kolmogorov-Smirnov. Pada taraf signifikansi 5\%, apabila nilai $\mathrm{D}_{\text {hitung }}<$ tabel Kolmogorov Smirnov, maka sebaran data kedua kelompok berdistribusi normal. Rekapitulasi hasil uji normalitas sebaran data secara rinci disajikan pada tabel 1 .

Tabel 1. Rekapitulasi Hasil Uji Normalitas Data Postes Kelompok Eksperimen

\begin{tabular}{lcccc}
\hline Kelompok Eksperimen & $\begin{array}{c}\text { Total } \\
\text { Sampel }\end{array}$ & $\begin{array}{c}\text { Nilai } \\
\mathbf{D}_{\text {hitung }}\end{array}$ & $\begin{array}{c}\text { Nilai } \mathbf{D}_{\text {tabel }} \\
\text { Kolmogorov Smirnov }\end{array}$ & Keterangan \\
\hline $\begin{array}{l}\text { Kelas IV SD Negeri 14 } \\
\begin{array}{l}\text { Dauh Puri } \\
\text { Kelas IV SD Negeri 10 }\end{array}\end{array}$ & 32 & 0,112 & 0,224 & $\begin{array}{c}\text { Berdistribusi } \\
\text { normal } \\
\text { Dauh Puri }\end{array}$ \\
\hline
\end{tabular}

Berdasarkan hasil uji normalitas kelompok eksperimen, diperoleh nilai $\mathrm{D}_{\text {hitung }}=$ 0,112 kemudian nilai tersebut dibandingkan dengan $D_{\text {tabel }}$ Kolmogorov Smirnov $=0,224$. Hal ini menunjukkan bahwa $D_{\text {hitung }}=0,112<D_{\text {tabel }}$ Kolmogorov Smirnov $=0,224$ yang berarti data hasil belajar IPA kelompok eksperimen berdistribusi normal. Dari hasil uji normalitas kelompok kontrol, diperoleh nilai $\mathrm{D}_{\text {hitung }}$ yaitu 0,154 kemudian nilai tersebut dibandingkan dengan $\mathrm{D}_{\text {tabel }}$ Kolmogorov Smirnov $=0,210$. Hal ini menunjukkan bahwa $D_{\text {hitung }}=0,154<D_{\text {tabel }}$ Kolmogorov Smirnov $=0,210$ yang berarti data hasil belajar IPA kelompok kontrol berdistribusi normal.

Selanjutnya uji homogenitas dilakukan untuk menunjukkan bahwa perbedaan yang terjadi pada uji hipotesis benar-benar terjadi akibat adanya perbedaan varians antar kelompok, bukan sebagai akibat perbedaan dalam kelompok. Uji homogenitas varians dalam penelitian ini menggunakan uji F. Pada taraf signifikansi 5\% dengan derajat kebebasan (dk) untuk pembilang $\mathrm{n}_{1}-1(32-1=31)$ dan derajat kebebasan $(\mathrm{dk})$ untuk penyebut $\mathrm{n}_{2}-1(37-1=36)$ diperoleh $\mathrm{F}_{\text {tabel }}=1,77$. Berdasarkan analisis, diperoleh $\mathrm{F}_{\text {hitung }}=$ 1,29. Hal ini berarti $\mathrm{F}_{\text {hitung }}=1,29<\mathrm{F}_{\text {tabel }}=1,77$ sehingga data kedua kelompok memiliki varians yang homogen. Rekapitulasi hasil uji homogenitas untuk sampel penelitian ini disajikan pada tabel 2 .

Tabel 2. Rekapitulasi Hasil Uji Homogenitas Sampel Penelitian

\begin{tabular}{lccccc}
\hline Kelompok & $\mathrm{S}^{2}$ & $\mathrm{dk}$ & $\mathrm{F}_{\text {hitung }}$ & $\mathrm{F}_{\text {tabel }}$ & Keterangan \\
\hline Eksperimen & 66,547 & 31 & \multirow{2}{*}{1,29} & \multirow{2}{*}{1,77} & Homogen \\
Kontrol & 51,419 & 36 & & & \\
\hline
\end{tabular}

Berdasarkan uji prasyarat analisis yang telah dilakukan, diperoleh data kedua kelompok sampel berdistribusi normal dan memiliki variansi yang homogen. Maka 
selanjutnya dilakukan uji statistik menggunakan uji-t dengan rumus polled varians. Rekapitulasi hasil uji-t dapat disajikan pada tabel 3.

Tabel 3. Rekapitulasi Hasil uji Hipotesis Sampel Penelitian

\begin{tabular}{lccccccc}
\hline \multicolumn{1}{c}{ Sampel } & $\begin{array}{c}\text { Rata- } \\
\text { rata }\end{array}$ & Varians & $\mathbf{d k}$ & $\mathbf{N}$ & $\mathbf{t}_{\text {hitung }}$ & $\mathbf{t}_{\text {tabel }}$ & Kesimpulan \\
\hline Kelas Eksperimen & 87,031 & 66,547 & 67 & 32 & 6,611 & 1,993 & H0 ditolak \\
Kelas Kontrol & 75,432 & 51,419 & & 37 & & & \\
\hline
\end{tabular}

Kriteria pengujian hipotesis yaitu jika thitung $\leq \mathrm{t}_{\text {tabel }}$, maka $\mathrm{Ho}_{\mathrm{o}}$ diterima dan, dan jika thitung $>\mathrm{t}_{\text {tabel }}$ maka $\mathrm{H}_{\mathrm{O}}$ ditolak. Pada taraf signifikan 5\% dengan $\mathrm{dk}=\mathrm{n}_{1}+\mathrm{n}_{2}-2$. Berdasarkan hasil perhitungan uji $\mathrm{t}$ diperoleh hasil $\mathrm{t}_{\text {hitung }}=6,611$ pada taraf signifikansi $5 \%$ dengan $\mathrm{dk}=$ $\mathrm{n}_{1}+\mathrm{n}_{2}-2=32+37-2=67$ menunjukkan nilai $\mathrm{t}_{\text {tabel }}=1,993$. Berdasarkan hal tersebut diperoleh $\mathrm{t}_{\text {hitung }}=6,611>\mathrm{t}_{\text {tabel }}=1,993$. Karena nilai $\mathrm{t}_{\text {hitung }}>\mathrm{t}_{\text {tabel }}$ maka dapat disimpulkan $\mathrm{H}_{0}$ ditolak (gagal diterima). Hal ini berarti terdapat perbedaan yang signifikan hasil belajar IPA antarakelompok eksperimen dan kelompok control pada kelas IV SD Negeri Gugus II Teuku Umar Denpasar Barat Tahun ajaran 2019/2020.

Hasil analisis data hasil belajar IPA diperoleh nilai rata-rata pada kedua kelompok yaitu pada kelompok eksperimen $X=87,031$ dan pada kelompok kontrol $X=75,432$. Dari hasil pengujian asumsi diketahui bahwa sebaran data hasil belajar IPA siswa berdistribusi normal dan memiliki varians yang homogen, uji hipotesis menggunakan uji t dengan rumus polled varians. Dari hasil analisis diperoleh $\mathrm{t}_{\text {hitung }}=6,611$ pada taraf signifikansi $5 \%$ dengan $\mathrm{dk}=67$ diperoleh $\mathrm{t}_{\text {tabel }}=1,993$. Oleh karena $\mathrm{t}_{\text {hitung }}=6,611>\mathrm{t}_{\text {tabel }}=1,993$ maka H0 ditolak yang menyatakan tidak terdapat perbedaan yang signifikan hasil belajar IPA kelompok siswa yang dibelajarkan melalui model pembelajaran kooperatif tipe Course Review Horay berbantuan media visual dengan kelompok yang dibelajarkan melalui pembelajaran konvensional pada kelas IV SD Negeri Gugus II Teuku Umar Tahun Pelajaran 2019/2020 ditolak. Selain itu nilai rata-rata kelompok eksperimen $X=87,031>X=75,432$ pada kelompok kontrol. Perbedaan nilai rata-rata yang diperoleh dari kelas eksperimen yaitu kelas IV SD Negeri 14 Dauh Puri yang terpaut jauh dengan kelompok kontrol yaitu kelas IV SD Negeri 10 Dauh Puri yang menunjukkan bahwa perlakuan dengan menggunakan model pembelajaran kooperatif tipe Course Review Horay berbantuan media visual berpengaruh terhadap hasil postest hasil belajar IPA siswa kelas eksperimen.

\section{PEMBAHASAN}

Pendidikan di tingkat sekolah dasar sangatlah penting untuk membekali siswa, agar siswa dapat hidup dalam bermasyarakat untuk dapat mencapai tujuan pendidikan. Tujuan dalam memberikan pembelajaran dalam bidang IPA yaitu agar siswa terampil dalam memecahkan suatu permasalahan yang ada dalam kehidupan sehari-harinya dan menerapkannya di kehidupan nyata. Dalam pelaksanaan pembelajaran IPA siswa diminta untuk mengerti dan mengenal konsep pembelajaran yang telah diberikan. Tujuan dalam memberikan pembelajaran IPA yaitu agar siswa trampil dalam memecahkan suatu permasalahan yang ada dalam kehidupan sehari-harinya dan menerapkannya dikehidupan nyata. Menurut Prameswari, K. K., Wiyasa, I. K. N., \& Ganing (2017) , IPA merupakan ilmu pengetahuan yang mempelajari segala kejadian alam beserta isinya berupa fakta, 
kenyataan dan kejadian yang sistematis dan tersusun. Sedangkan Widyantari (Widyantari, K. N., Putra, M., \& Wiarta, 2019) menyatakan bahwa IPA adalah suatu kumpulan faktafakta yang disusun secara sistematis yang mengkaji tentang gejala-gejala alam melalui hasil observasi, yang diperoleh dari pengalaman melalui serangkaian proses kegiatan ilmiah antara lain penyelidikan, perumusan masalah, penyusunan hipotesis, dan pengujian hipotesis melalui eksperimen dengan menggunakan metode ilmiah dan penarikan kesimpulan. Hal ini menegaskan bahwa pembelajaran IPA sangatlah penting bagi siswa dalam pembelajaran untuk memecahkan permasalahan dalam kehidupan sehari-harinya.

Berdasarkan temuan hasil penelitian yang dipaparkan diatas, terbukti adanya perbedaan hasil belajar yang signifikan antara kelompok eksperimen dan kelompok kontrol. Perbedaan yang signifikan terhadap kedua sampel disebabkan adalah treatment menggunakan model pembelajaran kooperatif tipe Course Review Horay berbantuan media visual yang diterapkan pada kelompok eksperimen. Model pembelajaran Course Review Horay merupakan merupakan salah satu model pembelajaran kooperatif dengan cara mengelompokkan siswa kedalam kelompok-kelompok kecil. Model pembelajaran Course Review Horay adalah salah satu pembelajaran dengan permainan dengan menggunakan kotak diisi nomor soal dan siswa mengerjakan soal sesuai dengan nomor yang ada di dalam kotak tersebut. Pembelajaran dengan pola permainan seperti ini tentunya akan sangat mampu meningkatkan minat dan motivasi siswa dalam pembalajaran karena berbalut dengan suasana yang menyenangkan.

Berkenaan dengan model pembalajaran kooperatif tipe Course Review Horay, banyak temuan studi yang juga membuktikan peran model pembelajaran kooperatif tipe Course Review Horay dalam pembelajaran. Beberapa temuan dan literasi yang memaparkan penjelasan mengenai model pembelajaran Course Review Horay diantaranya yakni Kurniasih, (n.d.) yang menjelaskan bahwa model pembelajaran Course Review Horay merupakan model pembelajaran yang dapat menciptakan susasana kelas menjadi meriah dan menyenangkan karena setiap siswa yang dpat menjawab benar maka siswa tersebut diwajibkan berteriak "hore" atau yel-yel lain yang disepakati. Sedangkan menurut (Rusman., 2016) Pembelajaran kooperatif (Cooperatife Learning) merupakan bentuk pembelajaran dengan siswa belajar dan bekerja dalam kelompok-kelompok kecil secara kolaboratif yang anggotanya terdiri dari empat sampai enam orang dengan struktur kelompok yang bersifat heterogen. Pada hakikatnya pembelajaran kooperatif sama dengan kerja kelompok. Jadi, Model pembelajaran Course Review Horay itu adalah model pembelajaran kooperatif, dimana siswa belajar secara berkelompok, setelah memberikan sajian materi mereka berdiskusi dan menjawab pertanyaan serta meninjau kembali jawaban mereka, apabila benar siswa berteriak horay atau menyampaikan yel-yel. Model ini berusaha menguji pemahaman siswa dalam menjawab soal, dimana jawaban soal tersebut dituliskan pada kartu atau kotak yang telah dilengkapi nomor. Siswa atau kelompok yang memberi jawaban benar harus langsung berteriak 'hore' atau menyanyikan yel-yel kelompoknya. Model ini juga membantu siswa untuk memahami konsep dengan baik melalui diskusi kelompok.

Disamping temuan-temuan tersebut masih ada penelitian-penelitian lain yang turut mendukung dari temuan penelitannya. Prameswari, K. K., Wiyasa, I. K. N., \& Ganing (2017) meneliti Pengaruh model pembelajaran course review horay berbantuan media lingkungan tehadap hasil belajar siswa. Penelitianya membuktikan bahwa model pembelajaran course review horay berbantuan media lingkungan berkontribui dalam 
peningkatan hasil belajar siswa (Prameswari, K. K., Wiyasa, I. K. N., \& Ganing, 2017). Temuan yang sama juga juga diperoleh Pratama, G. H. A., Renda, N. T., \& Pudjawan (2018). Temuan penelitiannya berkesimpulan bahwa model pembelajaran course review horay berbantuan media audio visual berpengaruh terhadap hasil belajar siswa (Pratama, G. H. A., Renda, N. T., \& Pudjawan, 2018). Penelitian berikutnya dilakukan oleh Khasanah, U., Rasiman, \& Wijayanti (2019). Melalui penelitiannya berhasil menyimpulkan bahwa model course review horay berbantu media kartu pecahan efektif meningkatkan hasil belajar (Khasanah, U., Rasiman., \& Wijayanti, 2019). Penelitian serupa juga dilakukan oleh Widyantari, K. N., Putra, M., \& Wiarta yakni mengenai pengaruh model pembelajaran course review horay terhadap kompetensi pengetahuan IPA. hasil penelitiannya membuktikan bahwa model pembelajaran course review horay berpengaruh terhadap kompetensi pengetahuan IPA siswa (Widyantari, K. N., Putra, M., \& Wiarta, 2019). Penelitian lain yang berkaitan dengan model pembelajaran Course Review Horay dilakukan oleh Anggraeni dkk. Penelitiannya membuktikan bahwa penerapan model course review horay berperan dalam meningkatkan aktivitas belajar IPA siswa sekolah dasar (Anggraeni, V. Y., Iriawan, S. B., \& Hermawan, 2019).

Tidak hanya model yang tepat, media yang seuai diterapkan pada suatu model juga turut ambil bagian dalam meningkatkan hasil belajar siswa. Pembelajaran akan lebih menyenangkan jika dibantu dengan media pembelajaran yang tepat. Penggunaan media visual dalam pembelajaran IPA di SD berupa gambar, foto, bagan atau peta pikiran (mind maping) dengan dikembangkan melalui kreasi yang menarik perhatian tentunya sangat mampu dalam meningkatkan semangat belajar siswa (Diarsa, I. P., Murda, I. N., \& Dharmayanti, 2017). Menurut Dewi, A. A. I. D. P., \& Arini (2018) Media pembelajaran visual memegang peranan yang sangat penting dalam kegiatan pembelajaran karena media pembelajaran visual dapat memperlancar pemahaman dan memperkuat ingatan. Visual dapat pula menumbuhkan motivasi siswa serta dapat memberikan hubungan antara isi materi pelajaran dengan dunia nyata.

Terdapat beberapa penelitian yang mendukung temuan penelitian ini terkait temuan dalam penelitian ini yang membuktikan adanya peranan media visual terhadap hasil belajar IPA, Penelitian tersebut diantaranya adalah penelitian yang dilakukan oleh Rosiana. penelitian ini menggunakan media visual sebagai variabel bebas, sementara itu perbedaannya pada yakni peneitian ini menggunakan model pembelajaran numbered head together. Hasil penelitian yang dilakukannya membuktikan bahwa media visual yang dipadukan dengan model pembelajaran NHT berpengaruh terhadap peningkatan hasil belajar siswa (Rosiana, N. M. Y., Sudana, D. N., \& Tastra, 2017). Penelitian lainnya yaitu penelitian yang dilakukan oleh oktariani. Hasil penelitian yang dilakukan juga membuktikan bahwa berkesimpulan bahwa model pembelajaran teams games tournament berbantuan media visual berpengaruh terhadap kompetensi pengetahuan IPA (Oktarianingsih, N. L., Abadi, I. B. G. S., \& Putra, 2019).

Dari semua yang menjadi temuan dalam penelitian ini membuktikan bahwa model Course Review Horay berbantuan Visual baik diterapkan dalam melaksanakan proses pembelajaran. Keberhasilan dalam penggunaan model Course Review Horay berbantuan Visual dilihat pada pelaksanan proses kegiatan pembelajaran siswa untuk memecahkan masalah dengan berdiskusi kelompok dan dengan adanya bantuan media Visual pmbelajaran menjadi aktif, kreatif dan pembelajaran lebih mudah dimengerti serta dipahami. 


\section{SIMPULAN}

Berdasarkan hasil analisis uji-t diperoleh nilai $\mathrm{t}_{\text {hitung }}=6,611$, dengan nilai $\mathrm{t}_{\text {tabel }}=$ 1,993 (pada taraf signifikansi 5\% dan $\mathrm{dk}=67$ ) ini berarti bahwa $\mathrm{t}_{\text {hitung }}=6,661>\mathrm{t}_{\text {tabel }}=$ 1,993. Berdasarkan kriteria pengujian, maka $\mathrm{H} a$ diterima. Dengan demikian dapat disimpulkan, model pembelajaran kooperatif tipe Course Review Horay berbantuan media Visual berpengaruh terhadap hasil belajar IPA kelas IV SD Negeri Gugus II Teuku Umar Denpasar Barat Tahun Ajaran 2019/2020. Adanya pengaruh ini menunjukkan bahwa model model pembelajaran kooperatif tipe Course Review Horay berbantuan media Visual berpesan dalam meningkatkan kualitas hasil pembelajaran melalui peningkatan suasana pembelajaran yang menyenangkan dengan melibatkan siswa secara aktif dalam proses pembelajarannya.

\section{DAFTAR PUSTAKA}

Agung, A. A. . (2014). Metodologi Penelitian Pendidikan. Aditya Media Publishing.

Agustin, N. K. T. J., Margunayasa, I. G., \& Kusmariyatni, N. N. (2019). Pengaruh Model Pembelajaran Tps Berbantuan Media Visual Terhadap Hasil Belajar IPA. Journal for Lesson and Learning Studies, 2(2), 239-249.

Anggraeni, V. Y., Iriawan, S. B., \& Hermawan, R. (2019). Penerapan Model Course Review Horay Untuk Meningkatkan Aktivitas Hasil Belajar Siswa Sekolah Dasar. Jurnal Pendidikan Guru Sekolah Dasar, 4(1), 205-216.

Arsyad, A. (2017). 7. Media Pembelajaran. Rajagrafindo Persada.

Aryastuti, N. M., Suarni, N. K., \& Kusmariyatni, N. (2017). Pengaruh Model Pembelajaran Kooperatif Tipe Course Review Horay Terhadap Keaktifan Dan Hasil Belajar IPA. Mimbar PGSD, 5(2), 1-11.

Dewi, A. A. I. D. P., \& Arini, N. W. (2018). Penerapan Model Pembelajaran Kooperatif Tipe Course Review Horay Berbantuan Media Visual Untuk Meningkatkan Hasil Belajar IPA. Jurnal Ilmiah Sekolah Dasar, 1(1), 1-9.

Diarsa, I. P., Murda, I. N., \& Dharmayanti, P. A. (2017). Pengaruh Model Pembelajaran Two Stay Two Stray Terhadap Hasil Belajar IPA Siswa. E-Journal PGSD Universitas Pendidikan Ganesha Mimbar PGSD, 5(2), 1-11.

Ega Rima Wati. (2016). Ragam media pembelajaran : visual-audio visual-komputer-power point-internet-interactive video (A. Jarot (ed.)). Kata Pena.

Khasanah, U., Rasiman., \& Wijayanti, A. (2019). Keefektifan Model Course Review Horay (CRH) Berbantu Media Kartu Pecahan Terhadap Hasil Belajar Matematika. Indonesian Journal Of Educational Research and Review, 2(1), 63-68.

Kurniasih, I. \& B. S. (n.d.). Ragam Pengembangan Model Pembelajaran untuk Peningkatan Profesionalitas Guru. Kata Pena.

Mahardita, G. A. M. C., \& Abadi, I. B. G. S. (2017). Pengaruh Pendekatan Pembelajaran Kontekstual Berbantuan Media Visual Terhadap Hasil Belajar IPA Siswa Kelas V. E-Journal PGSD Universitas Pendidikan Ganesha Mimbar PGSD, 5(2), 1-9.

Oktarianingsih, N. L., Abadi, I. B. G. S., \& Putra, D. B. K. N. S. (2019). ). Pengaruh Model Pembelajaran Teams Games Tournament Berbantuan Media Visual Terhadap Kompetensi Pengetahuan IPA. Jurnal Penelitian Dan Pengembangan Pendidikan, 3(3), 208-215.

Prameswari, K. K., Wiyasa, I. K. N., \& Ganing, N. N. (2017). Pengaruh Model 
Pembelajaran Course Review Horay (CRH) Berbantuan Lingkungan Sekolah terhadap Kompetensi Pengetahuan IPA Siswa Kelas V SD Gugus Kompyang Sujana Kecamatan Denpasar Utara. E-Journal PGSD Universitas Pendidikan Ganesha Mimbar PGSD, 5(2), 1-11.

Pratama, G. H. A., Renda, N. T., \& Pudjawan, K. (2018). Pengaruh Model Pembelajaran Crh Berbantuan Media Audio Visual Terhadap Hasil Belajar IPS. Journal for Lesson and Learning Studies2, 1(1), 52-63.

Rahmawati, F. F., \& Prasetya, Z. K. (2019). Pengaruh Model Corse Review Horay Terhadap Kemampuan Berpikir Analitis Siswa SD. Journal of Chemical Information and Modeling, 53(9), 1689-1699.

Rosiana, N. M. Y., Sudana, D. N., \& Tastra, I. D. K. (2017). Pengaruh Model Pembelajaran Numbered Head Together Berbantuan Media Visualterhadap Hasil Belajar IPS Siswa Kelas V SD Di Gugus IV Kecamatan Sawan Tahun Pelajaran 2016/2017. Mimbar PGSD Undiksha, 5(2), 2-9.

Rusman. (2016). Model-Model Pembelajaran:Mengembangkan Profesionalisme Guru. PT Rajagrafindo Persada.

Sari, I. G. A. K. D. P., Mahadewi, L. P. P, \& Rati, N. W. (2017). Pengaruh Model Pembelajaran Kooperatif Tipe Talking Stick Terhadap Hasil Belajar IPA Siswa Kelas V SD. Mimbar PGSD, 5(2), 1-11.

Sari, M. I., Riastini, P. N., \& Suarjana, I. M. (2017). Pengaruh Model Pembelajaran Course Review Horay Terhadap Aktivitas dan Hasil Belajar Kognitif IPA Siswa Kelas V. EJournal PGSD Universitas Pendidikan Ganesha Mimbar PGSD, 5(2), 1-11.

Septiawan, I. M. A. E., Rati, N. W., \& Murda, I. N. (2017). Pengaruh Model Pembelajaran Time Token Berbantuan Media Audio Visual Terhadap Hasil Belajar IPS. Jurnal Penelitian Dan Pengembangan Pendidikan, 2(3), 271-282.

Sugiyono. (2017). Metode Penelitian Kuantitatif, Kualitatif, dan R\&D. CV. Alfabeta.

Sulistyowati., W. (2015). Metodologi Pembelajaran IPA. PT Bumi Aksara.

Widura, I. D. G. S., Tegeh, I. M., \& Suwatra, I. I. W. (2018). Pengaruh Model Core Berbantuan Media Visual. Journal for Lesson and Learning Studies, 1(3), 258-267.

Widyantari, K. N., Putra, M., \& Wiarta, I. W. (2019). Pengaruh Model Pembelajaran Course Review Horay Berbantuan Media Question Card Terhadap Kompetensi Pengetahuan IPA. Journal for Lesson and Learning Studies, 2(3), 219-228.

Wiranata, I. M., \& Japa, I. G. N. (2018). Penerapan Model Pembelajaran Kooperatif Tipe Group Investigation (GI) Untuk Meningkatkan Hasil Belajar Matematika. Jurnal Ilmiah Sekolah Dasar2, 1(1), 39-48.

Yanthi, kadek N. (2017). Pengaruh Model Course review horay Berbasis Media audio Visual Terhadap Penguuasaan Kompetensi Pengetahuan IPA Siswa Kelas IV Sd Gugus VIII Mengwi Tahun Ajaran 2016/2017. Mimbar PGSD Undiksha, 5(2). 